\title{
PERSPECTIVES OF THE SOCIAL ECONOMY IN ROMANIA
}

\author{
Lucian SFETCU1 \\ Daniel POPA2
}

\begin{abstract}
For a sector with high development potential, like social economy in Romania, a precisely designed research method was used, focused rather on the future than the past or present status. The Delphi method can produce relevant information about evolution perspectives of any topic observed, mainly emergent facts or domains with uncertain progress. Initially developed in the Cold War context, to anticipate the impact of the technology on warfare, it starts from the premise that individual predictions were better than group ones. This tool aims to reach the best consensus on opinions from a group of experts within the specific domain studied, using questionnaires applied individually and mixed with relevant feedback from the researchers.

The present research used the Delphi technique and dedicated experts' contribution, in order to scrutiny analyze the evolution of the social economy in Romania, the current situation and the encountered problems, the legislative, institutional and fiscal framework and also how the European financial support works for this domain. Not least, a 10 year scenario is tested and advanced, along with some conclusions and questions for the future.
\end{abstract}

Keywords: Delphi method, Social economy

\section{Argument}

Social economy represents a large and increasing provider of social utility within a plural economy, between the capitalist and public sectors, with a major role in addressing new social issues. Social economy is a complex and diversified domain, through its organization forms, types of activities, and the way it interacts with public institutions and profit-oriented entities.

1 Assistant Professor, Ph.D., Department of Sociology and Social Work, Faculty of Philosophy and Social-Political Sciences, “Alexandru Ioan Cuza” University of Iasi, E-mail: lucian.sfetcu@gmail.com

2 Ph.D. Candidate, The Research Institute for Quality of Life, Romanian Academy, E-mail: iondanielpopa@iccv.ro 
All over the world, mainly in Europe, social economy is experiencing an accentuated development as an Amos response to the traditional economic systems generating new forms of social problems or perpetuating the existing ones.

The rising interest on this topic is due to organizations implementing projects financed by the European Social Fund, through the Sectorial Operational Program Development of Human Resources (POSDRU 2007-2013) and also the Operational Program Human Capital (2014-2020), and carries activities in social inclusion and employment of persons from vulnerable groups, but also promoting visibility raising activities. Also, the social economy is mentioned in Law no. 292/2011, as a sector of economic activities including social objectives, but it is the subject of two legislative (framework) proposals, submitted by the Ministry of Labor, in September and December 2011.

The current study aims to present the perspective of a number of researchers and experts in social economy, regarding the stage of this field in today's Romania, as well as its development perspectives in the Romanian social environment, as viewed in the middle of 2012. This research is part of a long-term effort of evaluating the social economy sector in Romania from the perspective of its development capacity in a midterm perspective. With the help of a group of experts, we realized a diagnosis of the social economy sector at the 2012 moment, and we also analyzed its potential 10-year development.

\section{Introduction}

Social economy has been, for a long time, a slightly studied topic in Romania, and the academic interest for the subject developed only in the last years, at the same time with the promotion of this concept by the European Union and with the financial support offered by Social European Fund, offered to organizations interested in developing this economy sector.

In the last years, some universities introduced the study of social economy in their curricula (Toronto University, Maastricht University, Bologna University, and others), the majority of scholars interested in researching this topic being sociologists or economists with a background in the study of the non-profit sector (also known as "the third sector"). In Romania, some universities (Babeș-Bolyai University from ClujNapoca, West University of Timisoara, Oradea University, and University Dimitrie Cantemir from Bucharest) managed to obtain European funding through POSDRU 2007-2013 and introduced master's programs in social economy.

Even if the research domain is new in Romania, the authors' connection to it, either through practice stages or volunteering in organizations involved in this field or through the implementation of financing programs within the responsible institutions, amounted to our growing scientific interest for this topic.

To study this novel but with a high development potential domain, we chose a research method designed precisely for this type of study, focusing on the future and less on the past or the current situation. Less used in Romania, the Delphi method produces important information about evolution perspectives of any study field, research, public 
policies, or merely of fresh ideas, very new or with uncertain progress but important to predict.

\section{Delphi Method}

\subsection{General description of the research method}

The mankind of all times wanted to know the future. For thousands of years, Greeks and Romans had been appeased the thirst for understanding the after time by calling the oracles. The name of this research method comes from the most popular one, the Delphi Oracle.

In Greek mythology, at the Delphi site was the most famous oracle, the place where Apollo God was worshiped, who might have been its owner after killing the dragon Pathos. Apollo used to communicate his prophecies through a woman called Pythia. All kinds of people, more important or not, from neighborhoods or far away, used to visit the oracle to receive personal or political advice or even to know how the wars ended.

The Delphi technique was developed at the beginning of the Cold War to anticipate the impact that technology might have on warfare in general (Custer, Scarcella and Stewart, 1999). In 1944, General Henry Arnold has requested US Air Force a report about the possibilities of technological development that might be used in the future in military conflicts, but the answer to this demand was not a satisfactory one, because the conventional future „prediction” was not enough studied and developed. Within a report sent to the Secretary of War, General Arnold wrote: „During this war, the Army, Army Air Forces, and the Navy have made unprecedented use of scientific and industrial resources. The conclusion is inescapable that we have not yet established the balance necessary to ensure the continuance of teamwork among the military, other government agencies, industry, and the universities. Scientific planning must be years in advance of the actual research and development work"'. The first type of Delphi research of high amplitude started in 1946 when Douglas Aircraft Company initiated the RAND project (from research and development) to study the eventual possibilities for intercontinental firearms. A multitude of already known techniques was put in practice, but these have not the expected success. There were interviews achieved, questionnaires were applied, trends were followed. The focus groups were the most closed to success, but their deficiencies (the influence of dominant personality or the pressure group) persuaded the researches that this is not the method to provide satisfactory results in the related conditions (Dalkey, 1969).

The RAND project developed the Delphi method from the premise that individual predictions were better than group ones, therefore they requested some experts for their individual opinion. Following data analysis and without a clear response, the researchers decided to ask once again the opinions of the same experts, explaining to them the reason, that a clear decision was not obtained the first time. The same experts were the subject of this process until the researchers were able to extract useful conclusions for their purpose. From this incipient stage, this method developed having

${ }^{1}$ http://www.rand.org/about/history.html, accessed on April 15, 2012 and June 10, 2020 
at this moment various versions and being used in many domains, including social (Edwards 2002; Sowell 1989).

Delphi method has been defined as a study unfolded in several stages, focused on obtaining a consensus from the interviewed persons. Delphi is a tool used to reach the best consensus on opinions from a group of experts within a specific domain, using a set of questionnaires applied individually, mingled with feedback from the researchers. The definition determines that the purpose of this method is to obtain a conclusion from several experts regarding a topic.

There are several varieties of the Delphi method, these being adapted to different situations or domains where it is applied. The classical version and, also, the original one, consists of two or more questionnaire rounds sent individually to a group of experts. These can be administered using an online panel, by phone, via email, post, or face to face. The first questionnaire contains open questions as general as possible regarding the topic targeted by researchers. The experts are asked to answer as widely as possible, openly, and creatively, to each of these questions. The answers are analyzed and rephrased by the researchers, are then returned to the respondents in a second round, in the form of statements or questions. The experts will rate each affirmation on a Likert scale, per the agreement level of each respondent with these statements. After this second round, the researchers analyze, quantitatively, the answers received to each item from the second questionnaire. If an initially agreed level of consensus is reached on all or part of the statements, the study is completed. If, on the other hand, a convenient level of consensus is not obtained, the second round is repeated until the desired degree of consensus is reached or, depending on the study design, the initially established number of attempts is reached.

Compared to the second round, the next ones contain, for each item, the answer provided by the expert in the previous round and also the consensus level reached by the entire panel of experts (Keeney, Hasson and H. McKenna 2011).

The Delphi method does not have, in all cases, the purpose of obtaining a consensus on a matter, but sometimes it can be used to identify research priorities in some domains. This form is used mainly in the academic sphere and mostly in the social sciences. In the public policy field, the Delphi method is used to discuss different points of view that arose on the brink of newly implemented policies or are pending implementation. The reason for which an agreement on a single usage mode for this method does not exist consists of the multitude of domains where this tool is used.

The Delphi method only requires the selection of some individuals from the population, those whose opinions are considered worth taking into consideration in a certain domain. The selected experts are persons with a high level of knowledge in that domain and can provide reliable information related to the topic. The participants should not know of each other, but this is not mandatory.

A very important feature of the Delphi method is that it is not meant to deliver good or bad, correct or wrong answers. The participants are requested to express their own opinions, endorsed or not by proofs, but for which there is no evidence requested at all. Even if a Delphi research may seem very similar to a focus group research, there are 
many differences between them, taking into consideration some criteria. First, the Delphi method provides at least partial anonymity for the participants, allowing them to respond freely to questions, without the constraint of group pressure. This anonymity allows, by case, the shift of participants' opinions in the third or subsequent rounds (Keeney et al. 2011).

The question of the Delphi method's adherence to a paradigm is still under debate. A classical Delphi study incorporates a qualitative stage and a quantitative one, which makes it difficult to position it. For the most part, the sociological literature appoints the Delphi method to the positivist paradigm (Day and Bobeva, 2005). Other authors consider this method should be categorized as an interpretative paradigm, namely social constructivism (Amos and Pearse, 2008), being considered a technique that uses subjective analysis and has a qualitative nature. Accepting the fact that the study subject of the Delphi research represents a succession of the participants' constructions of reality, it is clear this is not a positivist method. Blass (2003) concludes that, because the method extracts quantitative data from qualitative analysis, this method cannot be strictly positioned in one single paradigm, but it sits at the crossroad between positivism and social constructivism.

\subsection{Application}

The expert selection was conducted based on the criterion that each of them must have experience either in practice or studying social economy. All participants have a Ph.D. in sociology and experience in implementing social economy projects. The experts' profiles with relevant information are listed in Annex 1. The interviews and questionnaires were applied, depending on the availability of each respondent, face to face or online. The interview guide is listed in Annex 2, and the questionnaire is listed in Annex 3.

The first round consisted of a 4 question interview, intending to learn the experts' opinions about the status of social economy, the necessary steps for further development, the most relevant factors for the domain's evolution, and also to predict one or more scenarios for the 2022 horizon. For each question, the respondents provided, openly and independently, concise and extensive answers ideas, with descriptive details and real examples. All the answers were valuable and allowed us to outline their position regarding the research topic.

This stage's answers revealed that the experts' opinions were not majorly distinctive but revolving around the same disappointment towards the Romanian government and, at the same time, showing hope for the development potential of this sector.

The polarization of the experts' opinions was tested in the second round, where the experts were asked to rate their agreement about three sets of affirmations on a 1 to 7 Likert scale. In this round, the experts were presented with a total of 44 statements that resulted from the interviews' analysis. In short, each affirmation used in the second round was generated directly or indirectly by one or more open answers obtained in the first round. Following the analysis of the second-round answers, we noticed the expert's opinions were close and we obtained consensus on most statements, so a third round of questions was not necessary. 
From the 44 items, 25 were evaluated with between 4 and 7 by all experts, while for 16 items there was only one expert evaluation lower than 4 , while the rest of the experts gave a higher score. Only three affirmations from a total of 44 were evaluated radically different by the experts, as we show in Annex 3, this fact proving no internal contradiction to the other answers.

Apart from the quantitative part of checking the experts' consensus, the analysis is predominantly qualitative, the experts' opinions being similar. We will highlight the most important ideas resulted from our analysis and will try to correlate them with other information obtained from the interviews and from the scientific literature.

\section{Data analysis}

\subsection{The evolution of the social economy in Romania in the recent years}

It is a well-known fact that the social economy sector's evolution after 1990 was not a very encouraging one, and this trend doesn't seem to have left room for too many optimistic appraisals regarding the future of this domain, even if starting with the European fund's contribution after 2007, in promoting and developing it.

During the communist regime, the cooperatives were strictly controlled by the state, the farmers having no alternative but to the transfer of land in favor of the agricultural production cooperatives. This has led to the construction of a negative image among the population towards this form of economic organization.

For this reason, the first years after 1990 meant a dizzying decline of cooperatives, those during the communist regime being, for the most part, disbanded. In the 1990s, non-governmental organizations, associations and foundations, as opposed to cooperatives, saw a slight increase due to freedom of opinion with the removal of the Communist Party from the country's leadership. They have been active in various fields, especially where the state has failed to cope (Cace, Arpinte, and Scoican 2010).

„The evolution of non-profit organizations, mutual aid houses and cooperatives in recent years is not encouraging and there are no concrete forms of state support. Beyond the lack of a strategy for the social economy sector, there are no clear measures addressed to social economy organizations. Of the three types of entities, cooperatives are the ones with the sharpest decreases in the volume of activity and the number of employees. It is worrying that the unfavorable economic environment does not seem to be the main cause, considering that the average turnover and the number of employees has decreased constantly in recent years. "(S.C., May 2012)

The decline of the forms of social economy after 1990 is obvious, the only exception being, in the opinion of I.S., the mutual aid houses for pensioners (Arpinte, Cace and Cojocaru, 2010).

„The only, but major, exception are pensioners' mutual aid houses” (I.S., May 2012). The explanation for the smooth running of mutual aid houses for retirees is given by their very low dependence on the economic system. At the same time, retirees are not very interested in banks either, leaving the service of lending to the elderly in the service of 
mutual aid houses for pensioners, employees or other or other non-banking financial institutions.

However, the good functioning of mutual aid houses for pensioners is not a conclusive indicator for the evolution of the social economy, precisely because of their relative independence from the country's economy, while other forms of social economy are directly dependent on the economy and financial-banking system.

"The sector of consumer or craft cooperatives is represented almost symbolically in terms of job absorption [...] cases where these structures are directly aimed at increasing employment for disadvantaged groups are rather isolated' (S.C., May 2012).

This lack of correlation between the economic environment and the cooperative sector proves the clear shortcomings of the state in supporting these organizations which, although seemingly uninfluenced by economic factors, are in continuous decline, failing to become what they could be in a developed country, an important source of employment, especially for people from disadvantaged and socially marginalized groups.

Despite all the efforts made in recent years, both by the European Union and, to a lesser extent, by the Romanian government, it has not yet been able to answer one of the main problems that is, according to some definitions of the social economy, finding a solution to increase the number of jobs. Structures such as non-profit organizations, mutual aid houses or cooperatives have failed to absorb a significant number of people from vulnerable groups, due in large part to policies to support these types of organizations.

"The history of the social economy is reduced to mutual aid houses and cooperatives, these being the only forms of organization in which people associated and shared profits equally". (C.L., May 2012). According to C.L., the only concrete forms of social economy are mutual aid houses and cooperatives.

This view is not shared by the other respondents, but it can be justified if taking into account the principle that the profit from the association of persons must be distributed equally to them. We think this his view is not wrong, but it should not be overlooked that, in addition to redistributing profits among the members of the organization, the social economy also means reinvesting profits in the organization, in the community, to help marginalized people or even for ecological purposes, a fact that may be too easily overlooked, when talking about the social economy.

The political class showed little interest in the fate of this sector, those interviewed in this study unanimously agreeing that there are not the politicians who need convincing of the benefits of the social economy, but people who have the opportunity to associate and help each other and people in their communities. However, it is the politicians who adopt the social policies and laws that govern this sector, and their internalization of the concept of social economy is relevant at least enough to lead them to take actual measures to support it. 
"All these people, because this is about mentality, because people do not have, because they do not think. they can have and then I think that an important role is played by counseling, mentoring among these people and their effective support, tutoring to develop social economy" (C.L., May 2012).

This idea of tutoring may be a good one, but not necessarily effective. The social economy was born from the desire of people to solve various problems on their own. The tutoring can have an informative role, so that the people who could organize themselves in various forms do not go through all the exploratory steps and trials that those before them had to go through. At the same time, tutoring can give rise to ideas, can highlight needs that people did not know before learning about the social economy.

Through intervention on various types of disadvantaged or marginalized social categories, their balance changes and those who intervene in any way must be aware of the direct or indirect effects, desired or not, of their intervention. By this, we bring into question the fact that the inability of those who could intervene through various methods, to meet their newly created needs, can ultimately be harmful if these people are not given more than information. People need to realize their own needs and not to be told from the outside that they have or should have certain needs.

Both in Romania and in other countries in Central and Eastern Europe, especially in countries that joined the European Union in the last two waves of accession (Bulgaria, Czech Republic, Poland), recent years have been strongly marked by the affluence of European funds. This resource has been and still is available in almost all the important fields (agriculture, industry, education, medicine, social work, etc.). Unfortunately, for many of these countries, most of the public institutions tasked to manage these funds failed to manage them properly. This led to problems within countries, but also at the Union level. With the advent of problems in the world's economic systems, many people questioned the capitalist system and looked at social economy as an alternative. In this context, social economy received and still receives a lot of attention and large amounts of funds, both in Romania and in the other states.

\subsection{The current state of the social economy in Romania}

First, the social economy sector in Romania is dominated by the insertion of European funds. This funding influx led to a dizzying increase in the importance given to this sector and it is expected that this external influence will continue at least until 2020, fact that is confirmed by the Europe 2020 Strategy in which sustainable development of the social economy sector is one of the main objectives.

Given that it is a recent member of the European Union, somehow Romania was taken by surprise by the funding directed towards social economy, the concept being almost unknown before 2007. Even though the practice of the social economy existed under other names, it was not given so much importance before this year. "Romania is in an exploratory stage in which (a) the state of the sector and the directions of action are identified, (b) a series of specific intervention models for disadvantaged groups are experienced on a small scale" (D.A., May 2012).

For the most part, the fields of actions are proposed, in the present context, by the financing priorities established by the European Social Fund. There is indeed freedom 
of action and choice of actions course, but at a certain level, the development depends very much on the European Union's objectives.

The models mentioned by D.A. are, for the most part, models taken from more developed countries, in which the social economy has a long tradition. This application of practices from other socio-cultural contexts is not necessarily the best solution, but as long as they are tested to see how they manifest in the context of Romania and they are not imposed from the start as good, might be a cheaper solution than starting from scratch.

A position worth mentioning is that adopted, in the context of European funding, by mutual aid houses and cooperatives, which, although eligible for Union funding, do not show a keen interest in these funds." What I find interesting is that neither the mutual aid houses nor the cooperatives are extremely open, interested in the financing lines currently existing in the social economy." (C.L., May 2012). This could be because of their low financial capacity and the responsibilities involved in accessing Community funds.

A solution to this problem, specific to small organizations, could be a guarantee from the government for possible loans that organizations could take to co-finance the projects they want to implement. An important component necessary for the development of the social economy in any state is the level of awareness of people and their attitude towards such activities. "At the moment we do not have clear initiatives and the pro-activity in which people get involved and achieve social economy, we only have some debut initiatives carried out within some projects” (C.L., May 2012).

Given that social economy specific initiative started from the awareness of needs by those concerned, it is directly deducible that, as long as there is no will from those directly involved, it is difficult to achieve anything concrete in this area. The projects funded by the European Union, like any project, have a limited lifespan, and those that will continue to operate after the funding is over, will be those that become sustainable, where people have understood the importance and have identified the necessary resources to continue the process.

\subsection{Legislative framework}

Although Romania has a tradition in the cooperative sector, which suffered alterations during the communist period, and for the non-profit sector, a continuous development can be seen although the national legislative framework is not yet harmonized with the Community policy proposals issued by the European Parliament or the European Commission, nor does it allow comparisons with the other Member States which have distinctly regulated the concept of social enterprise, social inclusion enterprise or similar entities.

Romania has major shortcomings in terms of legislation when it comes to encouraging the social economy. The importance and, at the same time, the seriousness of this affirmation is confirmed by the fact that all the experts who took part in this study underlined the problem of the national legislative framework. "Often, in Romania, solving a problem means a law that, most of the time, establishes an new institution (in a legal sense). 
Obviously, such an approach is very rarely successful. The social economy should not be perceived as a checkbox by the appearance in the Official Gazette of a law" (I.S., May 2012).

This statement denotes a clear dissatisfaction with the state, with the way it is run and, at the same time, expresses the desire for the social economy to be taken seriously by policymakers, and not treated superficially in order to move on to the next points on the political agenda.

After 1990, the associative sector in Romania experienced a sharp decline. Market liberalization has led to an acceleration of the development of the capitalist system in a hurry to regain distance from developed countries, during which time the non-profit sector has been neglected by so many individuals but especially by the state. „Measures are needed to stop the decline of existing entities and stimulate the creation of new ones" (I.S., May 2012). These measures are even more necessary as the whole world does not seem to be able to break away from the socio-financial crisis we are in, but to which we do not seem to find practical solutions.

Perhaps the most common solution for overcoming the crisis of the capitalist system is the social economy. Even if this is not openly acknowledged, the European Union recognizes the merits of this type of economy and seeks to develop it. Also, many specialists in this field consider that this would be the optimal solution for reconstructing the world economy, the social economy has entered the vocabulary of many specialists and countries in the 2000s.

A complete transition to the social economy is, of course, a utopia. The business environment has its merits and must be supported to the same extent as the social economy must be developed. Although they partially overlap, the two sectors are not mutually exclusive, and they have a real chance of coexisting. "I think that Romania still has some problems related to the legislation in the social economy because, after all, this trend of social economy is also a response to the savage capitalism in which we speak of profit that goes to a person or a small group of people but interest in the weak, the uneducated, the non-risky is very reduced from a capitalist perspective” (C.L., May 2012). This problem of the weak, uneducated, who do not risk, who do not have physical, mental, or material possibilities is not new, all states are always facing it.

However, the capitalism of recent years accentuated this imbalance, growing unemployment and increasingly thinning the middle class, with most of its representatives heading, unfortunately, to the lower class and only a few to the upper class. (Wilkinson and Pickett 2010).

Except for some legislative provisions, Romania faced a lack of mechanisms to support cooperatives, the same situation is encountered in the case of other types of social economy entities, fact that, as mentioned above, has significantly contributed to reducing the importance and scope of their activity. "In Romania there were no significant interventions to support the cooperatives" (S.C., May 2012).

The first step that Romania must take in supporting the social economy is, in the opinion of all those interviewed, to regulate the types of entities that can join this 
concept: "there are issues to be clarified at the legislative level and not only NGOs should be considered as social economy organizations" (C.L., May 2012).

This problem of regulating the types of enterprises, of delimiting each type and establishing their specific functions is not specific to Romania, these ambiguities also exist in other European states and, even more so, at the level of the European Union, between different states.

The legislative proposal currently under debate, are also taking into account other forms of organization that should be included under the social economy umbrella but, in an abusive way, some are conditioning the classification of NGOs and other types of organizations as belonging to the social economy, by their partnership with public institutions or large corporations (Social Alternatives, 2012). This type of conditioning should not exist, moreover, a larger number of types of organizations should be included in the social economy because they already carry out activities in this respect, although not regulated by law." As a general feature, except for NGOs, the other types indirectly address disadvantaged groups, without any sustained services and for the purpose of their social reintegration. However, by the nature of the activity and the focus of the work areas, they produce significant forms of indirect impact” (S.C., May 2012).

Recently, the idea of recognizing a new entity, namely the social enterprise, is being tested. Although authorized sheltered workshops, NGOs carrying out economic activities or cooperatives are categorized by some authors as social enterprises, this term does not exist in our country's legislation or of many other states.

The establishment, initially at the legislative level, of such a type of economic organization, can be beneficial, but not before regulating very well the types of organization already existing in Romania, to clearly differentiate them and to establish a series of criteria according to of which organizations are categorized as belonging to the social economy, the classical one, or maybe somewhere in the middle. "Romania lacks an adequate legislative framework to encourage the development of social economy activities" (S.C., May 2012)

This is not a recent fact, the lack of state institution's involvement in helping those without opportunities is a constant in Romania, this fact practically determining the emergence of many associations and foundations trying to cover this gap.

The lack of support from the public institutions for organizations trying to support vulnerable groups became increasingly evident with the onset of the economic crisis and the increased number of unemployed, once many NGOs and foundations active in this segment disappeared.

\subsection{Institutional framework}

Public institutions did not develop forms of support or facilities for the organizations included under the umbrella of the social economy because they did not have the legal support to do so, and, moreover, it seems to have appreciated that their activity not as important as that of commercial organizations. Some studies show that the involvement of public institutions in supporting this type of activity is arbitrary, often depending only on the desire of officials in those institutions to support or not the 
efforts of NGOs, associations, foundations, cooperatives or mutualities (Cace, Arpinte and Scoican, 2010).

Although, at first glance, we might be tempted to believe that, with the regulation of the domain, there is a need for new state institutions meant to ensure that the social economy moves in the desired direction, the experts interviewed in this study do not agree, stressing that there is no need to create new public institutions to regulate the social economy. These answers were provided on a background of aggravating problems of bureaucracy, and excessive centralization.

The draft of the social economy law speaks of the establishment of a National Commission for Social Economy, a commission subordinated to the Ministry of Labor, Family and Social Protection, with territorial county commissions.

"Institutions only create bureaucratic obstacles to the development of an area that, instead of being supported, is systematically slowed down [...] the officials are in no hurry to do anything until they find a way to make a profit from it" (I.S., May 2012). The opinion that the state should not get too involved, because this would make it difficult for this sector to develop, is almost unanimous, the experts participating in this study believing that the state should not coordinate the development of this field, but only to regulate.

"The state must not coordinate the field of social economy through institutions [...] they are driven by political interests" (D.A., May 2012). This opinion seems justified given that the social economy is considered the third sector, alongside the public and private sectors (Lèvesque et al. 2001), and not an enlargement of the public sector, as the legislative proposal for the social economy allows to be understood. "Public institutions show a low willingness to support structures that address vulnerable groups" (S.C., May 2012). This low availability is due to the lack of a legislative framework that would allow them to be more widely involved in supporting these groups and providing social services.

At the moment, although there are institutions that have to provide social assistance services, they are non-performing due to poor legal regulations but also the poor training of their employees, complementary to an unsatisfactory remuneration level.

An optimal solution would be for the state to develop the legislative and fiscal framework, to establish the control institutions but to leave the development of the field in the hands of those involved, in a similar way the market economy in our country is regulated, where the state provides a framework for development and is involved only at the macro level.

\subsection{Fiscal framework}

For the fiscal framework that regulates the social economy, important improvements are needed. Romania should adopt a more relaxed fiscal regime for the social economy, thus supporting its development." The state should provide tax facilities to social economy entities in general and especially to those who employ vulnerable and highly vulnerable people in relation to the labor market." (S.C., May 2012).

Indeed, the employment of vulnerable people in the labor market practically supports the state because it no longer has to provide aid to these people. Moreover, the 
integration of vulnerable groups into the labor market has long-term effects, contributing to increasing the homogeneity of incomes within the state and increasing the quality of life of those involved.

"More than just an additional request for the state budget, these facilities must be related to the social, economic and fiscal benefits involved in a larger number of employees." (S.C., May 2012). The employment of vulnerable people, such as beneficiaries of guaranteed minimum income or the reintegration into the labor market of former detainees can lead, both in the short, medium and long term, to a decrease in the number of "socially assisted" people and thus to an increase in the quality of life of the entire population. There are, therefore, fiscal arguments to support not only the business environment but also the social economy, as this can also be an important generator of jobs.

It is all the more important to support the social economy as the latter, more than the business environment, aims to include in the labor market people from vulnerable and socially marginalized groups who are now supported by the state and who will otherwise remain in the care of protection institutions.

\subsection{European Funding}

European funding played a very important role in Romania in recent years. Available for different domains, the funding can be accessed by many types of organizations, companies, institutions, and even private persons. There are constant discussions on this subject, both in the political sphere, but also in the economic and non-profit ones.

The European Social Fund has made over 3.648 billion euros available to Romania for the 2007-2013 timeframe, funds divided between the Operational Program for the Development of Administrative Capacity (OP DAC), with an allocation of 208 million euros (to which 38 million euros are added from the national public contribution) and the Sectoral Operational Program Human Resources Development (SOP HRD), with an allocation of 3,476 million euros (with 58.88 million euros from the national public contribution).

Specifically, within the Key Area of Intervention 6.1 Development of the Social Economy, the social economy initially enjoyed a dedicated allocation of 420 million euros, almost $10 \%$ of the entire program budget (SOP HRD Implementation Framework Document, version 1 of February 2008²).

Subsequently, following the reallocation of funds to other measures to support social inclusion for vulnerable groups and the promotion of equal opportunities and, implicitly, by amending the Implementation Framework Document (version 4 of June $2010^{2}$ ), the budget allocated to the sector was reduced to EUR 285 million. So far, four calls for projects have been launched, with a total value of over 223 million euros, and as a result of this process, 60 projects have been selected, the first to start contributing to the development of the sector and increasing visibility. Within the Annual

\footnotetext{
${ }^{1}$ www.fseromania.ro/posdru/ accessed on April 15, 2012 and June 10, 2020

2 www.fseromania.ro/posdru/ accessed on April 15, 2012 and June 10, 2020
} 
Implementation Report 2011 (approved on June 5, 2012) there are 144 structures of the social economy and 274 jobs established within the SOP HRD projects ${ }^{1}$.

The funds targeted for the development of the social economy are considered by the experts participating in this study in two different ways. " European funds are a great step in this direction, but a healthy social economy must be self-sustaining" (S.C., May 2012). We can see here that the merit of the financial contribution of the European Union is fully recognized, but only as a starting point. It remains the responsibility of social economy entities set up with or without the help of the European Union, to become sustainable, to survive without continuous foreign aid. From this finding, some questions arise, that requires an answer in future scientific endeavors, namely:

- If the social economy really needs to be self-sustaining, is the need for support from external sources still justified?

- If we do not start from the idea of a community that undertakes something to help itself, if we do not talk about people who set up social economy entities with a more social than material purpose, can we still talk about the social economy, are non-reimbursable financing from external sources still justified?

We cannot answer these questions here but leave this matter open for following researchers to tackle these questions and find proper answers. Another question is whether external aid must continue to be provided, if social economy entities still need to be supported by the European Union. "The existence of European money will attract projects and organizations, but they will be empty shapes" (I.S., May 2012). This scenario, although likely to satisfy many individuals and organizations, is not desirable if the goal is to build a solid social economy system that is able to take over many of the tasks of the current capitalist system, that is stable to external economic influences. A system built of organizations funded mainly from external sources is extremely vulnerable and dependent on the donor.

The continuation of the financial aid from the European Social Fund will have to be treated with a change of approach, given that the social economy projects from 2008 to 2012 have not yet generated a major impact for vulnerable groups, due both to the slow-moving Romanian authorities and the lack of training and experience of organizations and institutions eligible for these funds.

Following the idea of discontinuation of European aid for the development of social economy, now or in 2020, if the financial program of the European Social Fund for the period 2014-2020 includes funds for the development of the social economy, it will be especially important to cover the demand for specialists in the social economy area.

"An important factor for the development of the field in Romania would be the training of specialists" (C.L., May 2012). Access to as many funds as possible by higher education institutions is desirable in Romania, as anywhere in the world. The training of experts in the social economy may be all the more necessary as long as the universities have funds from the European Union, as Romania does not have a tradition in this field, future experts

${ }^{1}$ www.fseromania.ro/posdru/ accessed on April 15, 2012 and June 10, 2020 
having to study the models of other states to get out of the national paradigm influenced by imperfect legislation.

"We woke up with a social economy in our arms, even if here were some forms of social economy and now we tend to see a limitation of the social economy in terms of legislation in Romania" (C.L., May 2012). To successfully carry out the approach of training specialists in social economy, it is, therefore, necessary to have additional funds to the traditional ones, funds to finance study visits, or even internships in social economy organizations in countries where this domain is more developed than in our country.

\subsection{The social economy in Romania in 2022}

Because the initial purpose of the Delphi research method was to foresee the development of certain fields, sectors of activity, technologies, etc., and because we had the opportunity to interview highly trained experts especially in sociology, but also in psychology or economics, all of them having carried out research, development, and promotion of the social economy, we asked their opinions on the possibilities of medium-term development of the social economy in our country.

Considering an interval of 10 years, in this case, the year 2022, we requested from each of them, an exercise of imagination, a short virtual leap into the future. The exercise of imagination, supported with more or fewer arguments, was a fruitful one, outlining several scenarios that Romania could experience in 10 years. For the most part, opinions were optimistic but nuanced, as they were not identical but often overlapped.

The possibility of the disappearance of the cooperative sector was discussed, but this was offset by a very strong sector of non-governmental organizations with a major role in the development of the social economy. In the same scenario, mutual aid organizations could retain their importance but only in small rural or urban areas, focusing on disadvantaged and low-income groups. Banks have begun to provide loans for the development of the social economy, loans directed mainly to non-governmental organizations.

If this trend continues, NGOs could indeed strengthen their market position and, through social economy activities, compete with small businesses, as the crisis in recent years put a very big question mark on the capabilities and the contemporary capitalist system.

The social economy can be an alternative, along with a change in the value system, a return to the social approach to the detriment of the economic approach, a twist to equal opportunities, to strengthening the middle class and to return to the humankind.

"I think we will have nowhere to go because we need to return more to the social approach, and this will not only be in our country but globally. The social vision will have a sufficient importance" (C.L., May 2012). Under these conditions, the social economy would develop with the changes in society. "One can imagine social enterprises, vulnerable groups to ensure their daily living being involved in a social enterprise" (C.L., May 2012).

Perhaps more important than European funds, than the laws adopted by Parliament or the efforts of a few people, the internalization by the general public of the role of all 
entities in the social economy, plays a very important role in the development of this field in the medium and long term. The social economy can improve the social protection system in Romania by supporting disadvantaged groups, by integrating people with disabilities, former detainees, victims of domestic violence, etc. into the labor market.

Another important area in which the social economy can bring important benefits is health. There have long been social hospitals in western countries and, more recently, in Romania (eg St. Nectarius Hospital in Bucharest), which provide medical services to people with no health insurance, as well as those who have but do not have the opportunity to access the services of traditional public hospitals.

In the field of credit industry, it is well known that the social economy can play a particularly important role in supporting low-income people without the possibility of obtaining bank loans.

Like agricultural production cooperatives coming from the communist regime, but without the same state intrusion, in the form of agricultural associations, small farmers can get better yields from their own crops. With an impressive arable land, Romania could become a major agricultural player if arable land were not so fragmented and people would move from subsistence agriculture, for their own consumption, to a more efficient, mass agriculture, which would bring, in addition to daily living, an increase in the quality of life of people in rural areas.

These are just some of the areas in which the social economy can play a very important role provided that the population and policy makers have an adequate understanding of this role and that they need to build an appropriate legal and fiscal framework.

For 2020, within an optimistic scenario of social economy development, changes are expected in the state structure, changes such as increasing the number of employees in the social economy sector and increasing the contribution of the social economy to the country's Gross Domestic Product. The role of the social economy in producing wellbeing is expected to be better understood by the population, this awareness being essential for a solid and long-term development.

Overall, although at the moment the social economy sector in Romania is not developed and, in the opinion of some specialists, is in decline, the general opinion is that in 10 years it will be much better, being a mature sector, along with the public and the private.

\section{Limits of the research}

Science is constantly evolving in any field, and in the social sciences as well, scientific approaches are, most of the time, cut-outs of moments in reality, viewed through a certain type of scientific lens and interpreted by researchers according to an established set of rules and their own personal experiences. Social reality is constantly changing, the lens through which it can be seen is not unique and the rules that the researcher uses in interpreting what he observes in the corner of reality studied are as many as the number 
of researchers. This work can be improved in a possible later approach, by involving a greater number of specialists in the social economy, from more diverse areas.

Because most of those whose opinions we obtained and interpreted here are theorists, we believe that diversification of experiences will be beneficial to a future study. Also, the geographical coverage was not uniform, being that the interviewed experts are only from Bucharest and Iasi, although working on national level projects, cannot provide a complete perspective of the social economy throughout the country.

\section{Conclusions and recommendations}

The social economy is, both as a practice, but especially as a theory, in an early stage of development worldwide and Romania is, unfortunately, far behind the developed countries in Europe and even on other continents regarding the practice of the social economy and its recognition by the state, by economic actors and, in general, by public opinion. As respects, the theoretical development, only the countries of Western Europe, such as France, Great Britain, Spain, Germany, and Italy have a more consolidated tradition and can be highlighted by significant contributions to this field.

Romania, from the academic and scientific development point of view, in the field of social economy, is at a very early stage, the vast majority of scientific papers on this field being published in recent years, under the umbrella of European-funded projects. The European Union places great emphasis on the development of the social economy in the Member States, as demonstrated by the growth targets adopted in the Europe 2020 Strategy (European Commission, 2010).

The question mark raised above capitalism by the socio-financial crisis of recent years makes the social economy gain this increased attention because this type of economy seems to be the most widely accepted and the best alternative to capitalism and there are hopes that it can be complementary to it.

For a solid and lasting development of the social economy, several steps are needed, this being a complex sector, which receives and transmits influences in a multitude of other spheres of society. Thus, we can outline the following findings and recommendations:

- Involvement of all responsible factors (relevant public institutions and relevant non-profit organizations) in designing an appropriate legislative framework, compatible with the specifics of existing actors in the local ecosystem and comparable to current guidelines in the European area, to support the growth of the social economy on the medium and long term is vital. In terms of participation in market exchanges, the social economy needs fiscal facilities to compensate the disadvantage compared to other players and to allow both the support of social activities (employment of vulnerable people, who are not always competitive in the labor market) and the creation of new jobs, as appropriate.

- The training of social economy specialists is essential, given both the growth potential of this sector and the lack or small number of people 
prepared or willing to pioneer social entrepreneurship. The initiatives of some universities to introduce master programs in social economy domain represent a good start of an approach that should be continued. Another option is the exchange of experience, the uphold of support networks (formal or informal) or the mentoring provided by social leaders who have been remarkably successful in starting community initiatives or creating social businesses. Social economy incubators, with support services for new businesses until they mature in the market, using lessons learned from other states, could be another launching pad.

- The effervescence that characterizes the discussions about the social economy today is due to the existence of funding sources and their accessibility. In the long run, we do not know what will happen after the closure of operational programs. If the field is no longer a priority in economic and social cohesion policy, then it should be supported by public funding, a national social program, or local grants. To the extent that social business proves to achieve its objectives, then it could attract the attention of the corporate private sector and funding through social responsibility programs.

- Also, public and other sources of funding are beneficial but need to be supplemented by a permanent public awareness campaign so that they understand the importance of the field, the benefits, and disadvantages, but especially to start responding to the supply of goods and services generated by social economy entities. The importance of the sector must be made known at all levels, including by policymakers who encourage and put in a positive light any such initiative. The long-term development of the social economy depends decisively on the awareness and internalization of this concept by community leaders, by entrepreneurs, by every person who wants to change something for the better, not as a pretext for accessing public funds, but as a tool that can increase the quality of life of small communities, and also of the entire population in Romania and in any other state, by integrating vulnerable groups on the labor market and, in general, in society. The social economy must be understood more deeply and by ordinary people, who can find in the specific forms of organization of the social economy, solutions to the needs they face, which they can approach creatively, in the communities they come from or in the group to which they belong.

- We must not forget the cooperative sector, which is currently in decline, having lost members, alienated assets, and is no longer playing a major economic role. Companies that survived so far need to be supported because they have passed the test of transition to a market economy, but they can no longer compete for a long time with new business models that act quickly, even aggressively or unconventional. Mutual aid organizations for pensioners and mutual aid organizations for employees remain a haven of financial inclusion for vulnerable people, in the absence of an adequate supply of financial products for such consumers. 
Of course, there are still questions for the future, which we must answer to help social economy actors perform, contribute through their work to increasing the well-being of vulnerable groups and creating added value in the community.

- How can we persuade people in the community to come up with ideas and develop business in and for the community?

- How can we overcome the dependence on external financial aid to create or develop an initiative?

- How can we ensure the sustainability of social economy initiatives?

- How can we demonstrate the need for grants as long as, in fact, the social economy must, at least in theory, start from within communities and not just through external influences?

Experience of recent years has shown that expectations of the impact of European funds for the social economy have not been sufficiently met, and that social enterprises at the heart of a healthy social economy are still to be expected.

\section{References}

Amos, T., Pearse N. (2008). Pragmatic research design: an illustration of the use of the Delphi technique. The Electronic Journal of Business Research Methodology 6(2):95-102.

Arpinte, D, Cace S, and Cojocaru S. (2010). Social economy in Romania. Preliminary approach, Review of research and social intervention 31:64-79.

Blass, E. (2003). Researching the future: method or madness? Futures 35:1041-1054.

Cace, S, Arpinte D., Scoican A. (coord). (2010). Economia socială în România: două profiluri regionale. Bucuresti: Editura Expert.

Cace, S, Arpinte D, Scoican A., Theotokatos H, Koumalatsou E. (2010). Economia socială în Europa. Bucuresti: Editura Expert.

Custer, R.L., Scarcella J.A., Stewart B.R. (1999). The modified Delphi technique - a rotational modification. Journal of Vocational and Technical Education 15(2):50-58.

Dalkey, N.C. (1969). An experimental study of group opinion: the Delphi method. Futures 1(5):408-426.

Day, J., Bobeva M. (2005). A generic toolkit for the successful management of Delphi studies. The Electronic Journal of Business Research Methodology 3(2):103-116.

Edwards, L.H. (2002). Research priorities in school nursing: a Delphi process. Journal of School Health 72(5):173-177.

Keeney, S., Hasson F., McKenna H. (2011). The Delphi technique in nursing and bealth research. Oxford: Wiley-Blackwell.

Lèvesque, B., Bourque G.L., Forgues E. (2001). Le nouvelle sociologie èconomique. Paris: Desclèe de Brouwer.

McKenna, H.P. (1994). The delphi technique: a worthwile approach for nursing? Journal of Advanced Nursing 19:1221-1225.

Sowell, R.L. (1989). Identifying HIV/AIDS research priorities for the next millennium: a Delphi study. Education Media International 26(2):115-124.

Wilkinson, R., Pickett K. (2010). The Spirit Level. Why equality is better for everyone. 3rd edition, London: Penguin Books. 
50 Perspectives of the social economy in Romania

*** (2012). Profit pentru oameni. Raport de deschidere în cadrul proiectului Modelul Economiei Sociale în România. Alternative Sociale, Iași.

European Commision (2010). 2020 Communication from the Commission: EUROPE 2020, A strategy for smart, sustainable, and inclusive growth, Bruxelles. Available at https://ec.europa. $\mathrm{eu} / \mathrm{eu} 2020 /$

FSE Romania. Available at http://www.fseromania.ro/index.php/posdru/informatii-generale/ fse\#fse. Accessed on 14-20 June 2012

*** Documentul Cadru de Implementare POSDRU 2007-2013. versiunea 1, ianuarie 2008

*** Documentul Cadru de Implementare POSDRU 2007-2013. versiunea 4, iunie 2010

*** Raportul anual de implementare POSDRU 2011, aprobat 5 iunie 2012 
Annex 1

\section{List of respondents}

\begin{tabular}{|l|l|l|}
\hline \multicolumn{1}{|c|}{ Initials } & \multicolumn{1}{|c|}{ Academic title } & \multicolumn{1}{c|}{ Representative positions } \\
\hline C.L. & PhD of Psychology & $\begin{array}{l}\text { Social programs coordinator; Expert in social economy } \\
\text { projects }\end{array}$ \\
\hline D.A. & PhD of Sociology & $\begin{array}{l}\text { Principal researcher of a research institute within the } \\
\text { Romanian Academy; Expert in social economy projects; } \\
\text { Associate Professor }\end{array}$ \\
\hline I.S. & PhD of Sociology & $\begin{array}{l}\text { Principal researcher of a research institute within the } \\
\text { Romanian Academy; Expert in social economy projects }\end{array}$ \\
\hline S.C. & $\begin{array}{l}\text { PhD of Economics } \\
\text { PhD of Sociology }\end{array}$ & $\begin{array}{l}\text { Principal researcher of a research institute within the } \\
\text { Romanian Academy; Social programs coordinator; } \\
\text { Expert in social economy projects; Public policies } \\
\text { evaluator for the Ministry of Labor; Public policies } \\
\text { evaluator for the Ministry of Finances; Associate } \\
\text { Professor }\end{array}$ \\
\hline
\end{tabular}


52 Perspectives of the social economy in Romania

Annex 2

\section{Interview plan}

Perspectives of the social economy in Romania - Delphi Study, Round 1

In the first round, we are kindly asking you to answer the following 4 questions.

For each question, please answer as detailed as possible (there is no space limit); the answers you give in this round are the basis on which the next rounds of research will be built.

Where do you think Romania is now in terms of the social economy?

What do you consider to be the steps to follow for the development of the social economy in Romania?

What do you think are the most important factors that contribute or will contribute to the evolution of the social economy sector in Romania?

How do you see the social economy sector in Romania in 2022?

(You can provide more scenarios with details on possible causes for each scenario). 


\section{Questionnaire}

Perspectives of the social economy in Romania - Delphi Study, Round 2

After analyzing the answers provided by you and the other participants in the first part of the study, we summarized a series of statements that we ask you to appreciate by giving them

"grades" depending on your level of agreement / disagreement regarding each of them.

1 - completely disagree; 2 - disagreement; 3 - some disagreement;

4 - indifferent;

5 - some agreement; 6 - agree; 7 - completely agree.

(You can highlight your answer in any way - underline, change color, delete, etc.)

\section{A. Where do you think Romania is now in terms of the social economy?}

\begin{tabular}{|l|c|c|c|c|c|c|c|}
\hline $\begin{array}{l}\text { Romania has experience in the Social Economy through mutuals } \\
\text { and cooperatives. }\end{array}$ & 1 & 2 & 3 & 4 & 5 & 6 & 7 \\
\hline $\begin{array}{l}\text { Romania is in an exploratory stage in which a series of specific } \\
\text { intervention models for disadvantaged groups are being } \\
\text { experimented on a small scale. }\end{array}$ & 1 & 2 & 3 & 4 & 5 & 6 & 7 \\
\hline $\begin{array}{l}\text { SE is now promoted in Romania exclusively due to the EU } \\
\text { financial year through the European Social Fund. }\end{array}$ & 1 & 2 & 3 & 4 & 5 & 6 & 7 \\
\hline $\begin{array}{l}\text { Romania faces a decline of the forms of social economy } \\
\text { (cooperative and mutual organizations), except for mutual aid } \\
\text { organizations for pensioners. }\end{array}$ & 1 & 2 & 3 & 4 & 5 & 6 & 7 \\
\hline $\begin{array}{l}\text { The cooperative sector lost many members, assets and scope of } \\
\text { economic activity from the Revolution until today. }\end{array}$ & 1 & 2 & 3 & 4 & 5 & 6 & 7 \\
\hline $\begin{array}{l}\text { Non-profit organizations, CARs and cooperatives have low } \\
\text { potential to develop social economy activities. }\end{array}$ & 1 & 2 & 3 & 4 & 5 & 6 & 7 \\
\hline $\begin{array}{l}\text { There is a lack of an adequate legislative framework for social } \\
\text { economy activities. }\end{array}$ & 1 & 2 & 3 & 4 & 5 & 6 & 7 \\
\hline $\begin{array}{l}\text { Public institutions do not support structures that address } \\
\text { vulnerable groups. }\end{array}$ & 1 & 2 & 3 & 4 & 5 & 6 & 7 \\
\hline Romania lacks a strategy for the social economy sector. & 1 & 2 & 3 & 4 & 5 & 6 & 7 \\
\hline $\begin{array}{l}\text { Romania is in an exploratory stage in which the state of the sector } \\
\text { and the directions of action are identified. }\end{array}$ & 1 & 2 & 3 & 4 & 5 & 6 & 7 \\
\hline $\begin{array}{l}\text { There are no clear initiatives, only attempts in EU-funded } \\
\text { projects. }\end{array}$ & 1 & 2 & 3 & 4 & 5 & 6 & 7 \\
\hline
\end{tabular}

Other suggestions: 


\section{Perspectives of the social economy in Romania}

\section{B. What do you consider to be the steps to follow for the development of the Social Economy in Romania?}

\begin{tabular}{|c|c|c|c|c|c|c|c|}
\hline $\begin{array}{l}\text { A unitary and coherent legislative framework governing SE } \\
\text { needs to be built. }\end{array}$ & 1 & 2 & 3 & 4 & 5 & 6 & 7 \\
\hline Funding is needed for practical ES activities. & 1 & 2 & 3 & 4 & 5 & 6 & 7 \\
\hline There is a need for a change in the mentality of people at risk. & 1 & 2 & 3 & 4 & 5 & 6 & 7 \\
\hline $\begin{array}{l}\text { There is a need for a change in the mentality of people with } \\
\text { political decision-making power. }\end{array}$ & 1 & 2 & 3 & 4 & 5 & 6 & 7 \\
\hline There is a need for a change in the mentality of businesspeople. & 1 & 2 & 3 & 4 & 5 & 6 & 7 \\
\hline It is necessary to support the existing cooperative sector. & 1 & 2 & 3 & 4 & 5 & 6 & 7 \\
\hline $\begin{array}{l}\text { SE incubators need to be developed to provide support on all } \\
\text { levels of new SE initiatives until they are stabilized. }\end{array}$ & 1 & 2 & 3 & 4 & 5 & 6 & 7 \\
\hline Support mechanisms are needed for protected workshops. & 1 & 2 & 3 & 4 & 5 & 6 & 7 \\
\hline Awareness of the need for ES is needed. & 1 & 2 & 3 & 4 & 5 & 6 & 7 \\
\hline Steps must be taken to halt the decline of $\mathrm{e}$ & 1 & 2 & 3 & 4 & 5 & 6 & 7 \\
\hline The establishment of new SE entities should be promoted. & 1 & 2 & 3 & 4 & 5 & 6 & 7 \\
\hline $\begin{array}{l}\text { Defining and legally recognizing the ES field is an important } \\
\text { step. }\end{array}$ & 1 & 2 & 3 & 4 & 5 & 6 & 7 \\
\hline $\begin{array}{l}\text { Clear legislative provisions must be formulated for each type of } \\
\text { SE entity. }\end{array}$ & 1 & 2 & 3 & 4 & 5 & 6 & 7 \\
\hline Tax facilities are needed for SE entities in general. & 1 & 2 & 3 & 4 & 5 & 6 & 7 \\
\hline $\begin{array}{l}\text { Tax facilities are needed for SE entities that employ vulnerable } \\
\text { people. }\end{array}$ & 1 & 2 & 3 & 4 & 5 & 6 & 7 \\
\hline $\begin{array}{l}\text { It is necessary to include SE entities in national and international } \\
\text { networks in order to intensify the exchange of products, } \\
\text { services and information between them. }\end{array}$ & 1 & 2 & 3 & 4 & 5 & 0 & 7 \\
\hline $\begin{array}{l}\text { The state must create tools for coordination and control of the } \\
\text { activity of SE entities, other than those existing for economic } \\
\text { operators. }\end{array}$ & 1 & 2 & 3 & 4 & 5 & 6 & 7 \\
\hline $\begin{array}{l}\text { There is a need to initiate communication channels between SE } \\
\text { entities and banks. }\end{array}$ & 1 & 2 & 3 & 4 & 5 & 6 & 7 \\
\hline $\begin{array}{l}\text { ES can only be developed through well-thought-out local } \\
\text { initiatives. }\end{array}$ & 1 & 2 & 3 & 4 & 5 & 6 & 7 \\
\hline $\begin{array}{l}\text { For the development of SE entities, support from local } \\
\text { authorities is needed. }\end{array}$ & 1 & 2 & 3 & 4 & 5 & 6 & 7 \\
\hline $\begin{array}{l}\text { The inclusion of SE entities in national and international } \\
\text { networks to intensify the exchange of products, services and } \\
\text { information with the economic agents themselves is a necessary } \\
\text { step. }\end{array}$ & 1 & 2 & 3 & 4 & 5 & 6 & 7 \\
\hline It is necessary to train specialists in ES. & 1 & 2 & 3 & 4 & 5 & 6 & 7 \\
\hline $\begin{array}{l}\text { The development of SE must be coordinated by state } \\
\text { institutions. }\end{array}$ & 1 & 2 & 3 & 4 & 5 & 6 & 7 \\
\hline
\end{tabular}

Other suggestions: 


\section{What do you think are the most important factors that contribute or will contribute to the evolution of the social economy sector in} Romania?

\begin{tabular}{|c|c|c|c|c|c|c|c|}
\hline $\begin{array}{l}\text { Involvement of Public Social Assistance Services in the development of } \\
\text { SE. }\end{array}$ & & 2 & 3 & 4 & 5 & 6 & 7 \\
\hline The policy makers must be aware about the importance of the sector. & 1 & 2 & 3 & 4 & 5 & 6 & 7 \\
\hline $\begin{array}{l}\text { Concrete forms of support are needed for SE entities through the ESF } \\
\text { 2014-2020, adapted to their capacities. }\end{array}$ & 1 & 2 & 3 & 4 & 5 & 6 & 7 \\
\hline The general public must be informed about all that ES means. & 1 & 2 & 3 & 4 & 5 & 6 & 7 \\
\hline $\begin{array}{l}\text { The organization of a critical mass of people informed about SE is } \\
\text { essential for the development of the field. }\end{array}$ & 1 & 2 & 3 & 4 & 5 & 6 & 7 \\
\hline $\begin{array}{l}\text { Legislation needs to be optimized to allow for the easy establishment of } \\
\text { SE entities. }\end{array}$ & 1 & 2 & 3 & 4 & 5 & 6 & 7 \\
\hline $\begin{array}{l}\text { It is necessary to introduce at the legislative level a new type of } \\
\text { organization - the Social Enterprise. }\end{array}$ & 1 & 2 & 3 & 4 & 5 & 6 & 7 \\
\hline $\begin{array}{l}\text { Expanding the ES area beyond the inclusion of vulnerable groups, to } \\
\text { promote a new type of organization of economic activity. }\end{array}$ & 1 & 2 & 3 & 4 & 5 & 6 & 7 \\
\hline It is necessary to inform people from public institutions on this topic. & 1 & 2 & 3 & 4 & 5 & 6 & 7 \\
\hline $\begin{array}{l}\text { Detaching SE entities from donors and funders is an impor } \\
n \text { their development. }\end{array}$ & 1 & 2 & 3 & 4 & 5 & 6 & 7 \\
\hline
\end{tabular}

Other suggestions: 